\title{
PENINGKATAN BUDAYA KESELAMATAN PASIEN MELALUI PEMBERDAYAAN CHAMPION KESELAMATAN PASIEN
}

\author{
Indah Pandiangan \\ Indahpandiangan13@gmail.com
}

\section{Latar belakang}

Budaya keselamatan pasien (KP) merupakan hal pokok dan mendasar dalam pelaksanaan KP di rumah sakit (RS). Setiap RS harus menjamin penerapan KP pada pelayanan kesehatan yang diberikannya kepada pasien. Upaya KP diawali dengan penerapan budaya KP. Budaya KP sebagai fondasi dalam usaha penerapan KP yang merupakan prioritas utama dalam pemberian layanan kesehatan. Fondasi KP yang baik akan meningkatkan mutu pelayanan kesehatan khususnya asuhan keperawatan. Penerapan KP memungkinkan perawat mencegah terjadinya kesalahan kepada pasien saat pemberian layanan kesehatan di RS. Hal ini dapat meningkatkan rasa aman dan nyaman pasien yang dirawat di RS. Pencegahan kesalahan yang akan terjadi tersebut juga dapat menurunkan biaya yang dikeluarkan pasien akibat perpanjangan masa rawat yang mungkin terjadi. Pelayanan yang aman dan nyaman serta berbiaya rendah merupakan ciri dari perbaikan mutu layanan. Perbaikan mutu pelayanan kesehatan dapat dilakukan dengan memperkecil terjadinya kesalahan dalam pemberian layanan kesehatan. Penerapan budaya KP akan mendeteksi kesalahan yang akan dan telah terjadi. Budaya KP tersebut akan meningkatkan kesadaran untuk mencegah error dan melaporkan jika ada kesalahan. Hal ini dapat memperbaiki outcome yang dihasilkan oleh RS tersebut. Dimensi-dimensi keselamatan pasien meliputi kerja sama tim antar unit; kerja sama dalam tim di unit RS; operan; frekuensi pelaporan kejadian; respon tidak menghukum terhadap kesalahan; komunikasi terbuka; umpan balik; pembelajaran organisasi; persepsi secara umum tentang KP. Masalah KP tidak hanya masalah individu atau salah satu kelompok. Penerapan KP melibatkan seluruh sistem yang ada di RS. Oleh karena itu kerja sama tim antar unit di RS sangat berperan dalam penerapan budaya KP yang pada gilirannya berperan dalam pelaksanaan KP di RS.Kerja sama tim sangat dibutuhkan dalam pelaksanaan KP. Setiap anggota tim bertanggung jawab dan bekerja sama untuk mencapai tujuan dengan perbedaan peran masing-masing yang spesifik. Perawat dapat bekerja sama dengan tenaga kesehatan lainnya seperti dokter dan apoteker dalam keakuratan pemberian obat pada pasien. Operan termasuk salah satu jenis komunikasi yang dapat dilakukan perawat dalam upaya 
menerapkan budaya KP. Perawat dapat berkomunikasi mengenai kesalahan yang telah terjadi atau yang mungkin terjadi dalam proses pemberian pelayanan kesehatan kepada pasien. Pelaporan kejadian merupakan suatu sistem yang penting dalam membantu mengidentifikasi masalah KP dan dalam menyediakan data pada organisasi sebagai sistem pembelajaran.

\section{Metode}

Metode yang digunakan dalam penelitian ini adalah metode penelitian kuantitatif pre-experiment pretestposttest without control group. Teknik pengambilan sampel pada penelitian ini menggunakan probability sampling yaitu simple random sampling. Sampel dipilih dari populasi yang memenuhi kriteria inklusi dan eksklusi. Pertimbangan dalam pemilihan sampel dilakukan peneliti adalah dengan menentukan kriteria inklusi dan eksklusi. Kriteria inklusi pada penelitian ini adalah semua perawat pelaksana yang (1) bersedia menjadi responden, (2) pendidikan minimal D3 Keperawatan, sedangkan kriteria eksklusi adalah perawat pelaksana yang sedang dalam masa tugas belajar dan izin belajar dan yang sedang cuti (cuti hamil, cuti menikah, cuti sakit).

\section{Hasil}

\section{Penerapan Keselamatan pasien}

Perawatan tidak aman Yang dilakukan oleh Petugas kesehatan dirumah sakit menjadi prioritas masalah yang harus segera diselesaikan' 83\% kejadian Yang menYebabkan Pasien tidak aman merupakan kejadian yang seharusnYa bisa dicegah dan 30o/o diantaranya berkaitan dengan kematian pasien.e Adanya tindakan yang tidak aman dikarenakan beberaPa faktor diantaranya tidak kurangnya pelatihan' pengawasan, kegagalan menindaklanjuti kebijakan.e PeneraPan budaYa keselamatan pasien dalam sebuah organisasi tidak ierlepas dari Peran aktif atasan (supervisor atau manajer dalam mempromosikan dan melakukan tindakantindakan yang mendukung berjalannya proses penanaman nilai yang dianut' Masih banYak Perawat Yang menganggap tindakan supervisor / manajer dalam memPromosikan keselamatan pasien masih rendah, karena masih adanYa Perawat Yang mengganggaP bahwa Peran aktif manajer dalam menanamkan niiai-nilai keselamatan pasien bisa dibilang kurang maksimal'10. Dan dapat disimpulkan bahwa masaiah utama Yang harus menjadi pricritas untuk diselesaikan adalah perawatan terhadap pasien yang tidak aman. Perlu ada Perubahan budaYa didalam rumah sakit 
agar budaya keselamatan pasien semakin baik. Budaya keselamatan yang baik dapat mengurangi risiko terjadinya kejaCian yang tidak diinginkan' Maka' diperlukan pelatihan secara rutin bagi petugas medis agar benar-benar nnernahami budaya keselamatan pasien' Pengawasan dari atasan juga harus ditingkatkan sebagai salah satu upaya untut $<$ menerapkan budaya keselamatan pasien. Semua itu harus didukung dengan kebijakan dari atasan dan semua Petugas medis harus bisa menindaklanjuti setiap kebijakan yang dibuat. Jika itu semua dilakukan maka budaYa keselamatan Pasien akan.

\section{Aspek Etika}

berjalan dengan baik Sampai saat ini tenaga keperawatan belum memiliki landasan hukum yang jelas dan pasti dalam memberikan pelayanan kesehaian. Menurut Peratui'an Pemerintah l'Jo 32 Tahun 1996 tentang Tenaga Kesehatan, hubungan perawat dan klien merupakan subjek hukum. Pemahan perawat mengenai hukum kesehatan memberikan keyakinan kepada perawat dan menjaga klien untuk selalu berada pada jalut yang aman dengan mengikuti standing order yang telah ditetapkan oleh profesi keperawatan dari pihak rumah sakit yang bersangkutan. Standing order merupakan Keselamatan Sakit, Depkes. Panduan Nasional Pasien Rumah kan pendelegasian kePada tenaga keperawatan dalam memberikan asuhan keperawatan atau pelayanan kesehatan. Dalam melaksanakan kewajibannya sebagai tenaga medis maka harus sesuai dengan kode etik atau etika yang telah ditetapkan. Hal ini dilakukan agar tenaga medis selalu mengutamakan keselamatan pasien dan tidak seenaknya melakukan tindakan medis yang tidak sesuai dengan standar.

\section{Pembahasan}

Hasil penelitian ini menunjukkan bahwa terdapat kenaikan pada skor penerapan budaya keselamatan pasien sebelum program pemberdayaan champion keselamatan pasien dibandingkan dengan setelah pemberdayaan champion keselamatan pasien. Hasil penelitian ini menjawab hipotesis bahwa tidak terdapat hubungan yang bermakna antara pemberdayaan champion keselamatan pasien terhadap penerapan budaya keselamatan pasien. Keselamatan pasien yang berjalan di RS tempat penelitian masih bersifat reaktif terhadap insiden yang terjadi dan belum berkembang ke arah penataan sistem yang baik. Tingkat maturitas budaya keselamatan pasien berada pada kategori tingkat maturitas reaktif, yaitu organisasi hanya berpikir tentang keselamatan pasien setelah terjadi insiden. Penerapan budaya keselamatan pasien tidak terlepas 
dari pembentukan capacity building. Pembentukan kelompok kecil efektif dalam peningkatan capacity building budaya keselamatan pasien dan mampu menyediakan lingkungan yang baik dalam proses belajar. Champion keselamatan pasien di rumah sakit tempat penelitian ditunjuk dari kepala ruangan. Hal ini diharapkan dapat lebih meningkatkan keterjangkauan program ke unit terkecil. Namun penunjukkan kepala ruangan sebagai champion meningkatkan beban kerja kepala ruangan yang sudah overload sehingga peran sebagai champion keselamatan pasien menjadi tidak optimal. Beberapa rumah sakit di Toronto menunjuk champion berdasarkan kriteria-kriteria tertentu. Kriteria tersebut berdasarkan pengalaman, kemampuan memimpin dan menjadi role model serta pengetahuan mengenai keselamatan pasien itu sendiri. Biasanya champion keselamatan pasien ditunjuk dari perawat senior yang berpengalaman dan sudah berada pada level supervisor. Penerapan ini di rumah sakit Indonesia belum sesuai. Hal ini dikarenakan supervisor pada rumah sakit di Indonesia juga mempunyai beban kerja yang tinggi serta rentang kendali yang cukup luas. Rentang kendali yang besar akan menyebabkan pengarahan yang diberikan menjadi kurang efektif Insiden keselamatan pasien tidak selamanya terjadi karena kesalahan manusia. Keselamatan pasien berhubungan dengan semua elemen di rumah sakit.

Banyak faktor yang mempengaruhi terjadinya insiden keselamatan pasien, tidak hanya kesalahan individu tetapi dapat juga diakibatkan oleh kesalahan system Sistem yang kurang tertata merupakan kondisi yang sering kali menjadi faktor pencetus terjadinya kesalahan dalam keselamatan pasien. Sistem yang tertata dengan baik adalah sistem yang memfasilitasi adanya kerja sama tim antar unit yang solid dan terintegrasi dalam mewujudkan tujuan keselamatan pasien. Organisasi pelayanan kesehatan harus mengembangkan budaya KP dengan tujuan yang jelas, prosedur yang tetap, dan proses yang aman. menyatakan budaya keselamatan dipengaruhi oleh perubahan orgasnisasi, seperti perubahan kepemimpinan atau pengenalan sistem baru. Suatu organisasi dengan budaya keselamatan yang lemah akan membatasi sistem keselamatan, sedangkan yang memiliki budaya positif akan mempunyai banyak cara yang tepat untuk mempromosikan KP. Program pemberdayaan champion keselamatan pasien dilakukan dalam waktu sebulan. Pada kurun waktu tersebut telah terjadi peningkatan pada penerapan budaya keselamatan pasien. Apabila program tersebut terus dilaksanakan secara terus menerus dan berkesinambungan, diharapkan penerapan budaya keselamatan pasien dapat mengalami peningkatan yang lebih baik. 
Peningkatan pengetahuan staf melalui diskusi yang dilakukan champion saat interaksi mengubah persepsi perawat pelaksana mengenai upaya keselamatan pasien yang dilakukan di RS. Hal ini meningkatkan kesadaran dan cara berpikir perawat dalam mempersepsikan keselamatan pasien itu sendiri. Budaya KP merupakan nilai, kepercayaan, yang dianut bersama dan berkaitan dengan struktur organisasi, dan sistem pengawasan dan pengendalian untuk menghasilkan norma-norma perilaku Hal ini melibatkan persepsi individu tersebut. Staf dengan persepsi baik terhadap KP akan memudahkan penerapan budaya KP. Namun pada RS tempat penelitian belum didukung oleh struktur organisasi dan system pengawasan yang optimal. Hal ini dapat menjadi faktor lain yang berperan dalam penurunan skor dimensi persepsi terhadap keselamatan pasien. Hasil penelitian ini memberikan informasi bahwa program pemberdayaan champion keselamatan pasien merupakan upaya positif dalam peningkatan penerapan budaya keselamatan pasien. Hal ini terlihat dari peningkatan penerapan budaya keselamatan pasien secara keseluruhan setelah dilaksanakannya program tersebut. Sebagian besar dimensi budaya keselamatan mengalami peningkatan setelah program pemberdayaan champion keselamatan pasien dilaksanakan, meskipun terdapat beberapa dimensi yang mengalami penurunan.

\section{Penutup}

Hasil penelitian ini menunjukkan bahwa terdapat kenaikan pada skor penerapan budaya keselamatan pasien sebelum program pemberdayaan champion keselamatan pasien dibandingkan dengan setelah pemberdayaan champion keselamatan pasien. Perubahan budaya memerlukan waktu yang lama. Oleh sebab itu, diperlukan pemberdayaan champion keselamatan pasien secara terus menerus agar penerapan budaya keselamtan pasien mencapai hasil yang optimal.

Penerapan budaya keselamatan pasien yang belum menunjukkan peningkatan yang signifikan setelah program pemberdayaan champion keselamatan pasien diterapkan salah satunya disebabkan oleh champion yang ditunjuk mempunyai jabatan ganda. Champion yang ditunjuk pada tempat penelitian juga merupakan kepala ruangan. Hasil penelitian ini memberikan implikasi bagi pelayanan dan pendidikan keperawatan untuk mengembangkan metode pengarahan sesuai dengan kebutuhan perawat rumah sakit. 


\section{Daftar Pustaka}

1. Mudayana.A.A.2014.Peran Aspek Etika Tenaga Medis Dalam Penerapan Budaya

Keselamatan Pasien Di Rumah Sakit.Suplemen Majalah Kedokteran Andalas,37(1).

2. Elrifda.S.2011.Budaya Patient Safety Dan Karakteristik Kesalahan Pelayanan :Implikasi

Kebijakan Di Salah Satu Rumah Sakit Di Kota Jambi.Jurnal Kesehatan Masyarakat,6(2).

3. Ezdha.A.U.A.Angreini.S.N.\&Fitri.D.E.2018.P engaruhu Pelatihan Keselamatan Pasien

Dengan Metode Ceramah Dengan Pemahaman Perawat Mengenai Penerapan Sasaran

Keselamatan Pasien Di Rs PMC Pekan Baru.Jurnal Kesehatan,1(8).

4. Herawati.Y.T.2015.Budaya Keselamatan Pasien Di Ruang Rawat Inap Rumah Sakit X

Kabipaten Jember.Jurnal IKESMA,2(1)

5. Iriviranty.A.2015.Analisi Budaya Organisasi Dan Budaya Keselamatan Pasien Di RSIA Budi Kemuliaan Tahun 2014.Jurnal ARSI,1(3)

6. Mandriani.E.Hardisman.\&Yetti.H.2019.Anali si Dimensi Budaya Keselamatan Paasien Oleh Petugas Kesehatan Di RSUD Dr Rasidin Padang Tahun 2018.Jurnal Kesehatan Andalas,8(1).

7. Najihah.2018.Budaya Keselamatan Pasien Dan Insiden Keselamatan Pasien Di Rumah Sakit:Literature Reveuw.Journal Of Islamik Nursing,3(1).

8. Nivalinda.D.Hartini.M.C.I.\&Santoso.A.2013. Pengaruh Motivasi Perawat Dan Gaya Kepemimpinan Kepala Ruang Terhadap Penerapan Budaya Keselamatan Pasien Oleh Peerawat Pelaksana Pada Rumah Sakit Pemerintah Di Semarang.Jurnal Managemen Keperawatan,1(2).

9. Pujilestari.A.Maidin.A.Angraeni.R.2014.Buda ya Keselamatan Pasien Di Instalasi Rawat Inap RSUP DR.Wahidin Sudirohusodo Kota Makassar.Jurnal MKMI,(57-64).

10. Suci.W.P.2018.Peningkatan Budaya Keselamatan Pasien Melalui Pemberdayaan Champion Keselamatan Pasien.JKH,2(2).(2548- 1843).

11. Simamora, R. H., \&Fathi, A. (2019). The Influence Of Training Handover Based SBAR Communication For Improving Patients Safety. Indian journal of public health research \& development, 10(9), 1280-1285. 
